Original Research Paper

\title{
Deafness Risk Estimation Analysis of Native Genetic Resource Kangal Shepherd Dog Breed: Sivas Province Example
}

\author{
${ }^{1}$ Mustafa Koçkaya, ${ }^{2}$ Yusuf Özşensoy and ${ }^{3}$ Hakan Murat \\ ${ }^{1}$ Department of Veterinary Physiology, \\ ${ }^{2}$ Department of Veterinary Biometrics and Genetics, \\ ${ }^{3}$ Department of Livestock Economics and Management, \\ Sivas Cumhuriyet University, Faculty of Veterinary Medicine, Sivas, Turkey
}

Article history

Received: 05-02-2019

Revised: 15-04-2019

Accepted: 09-05-2019

Corresponding Author:

Mustafa Koçkaya

Department of Veterinary

Physiology, Faculty of

Veterinary Medicine, Sivas

Cumhuriyet University, 58140,

Sivas, Turkey

Tel: +90 3462191812

E-mail: vet mustafakockaya@hotmail.com

\section{Introduction}

According to the literature, humans used dogs, which are the descendants of ancient wolves (Canis lupus), for the first time approximately 15000 to 100000 year ago in Eastern Asia (Jensen, 2007). It has been suggested that herd protection dogs are the first breeds among the domestic dogs used by humans (Dawydiak and Sims, 2004). Archeological findings in Hacilar and Catalhoyuk regions in Turkey, which date back to 7000 $\mathrm{BC}$, revealed the presence of domesticated dogs in Anatolia (Nelson, 1996). Farmers in history used dogs against wild animal attacks for protection of small farm animals (Coppinger et al., 1996). The fact that the Kangal shepherd dog breed has preserved its original characteristics without deterioration is explained by the popularity of these dogs among sheep breeders and by their unique vigilance against wolves (Yilmaz, 2008).
Kangal shepherd dogs and their pedigree-based breeding were mentioned in the Ottoman Imperial Archives (Cevik, 2011).

The largest known population of Kangal shepherd dog breed is located in Kangal, which is a small city in the Sivas province in Turkey and the most typical individuals of this breed are bred in this area. Therefore, the name "Kangal Shepherd Dog" has been given to this breed of dogs, which are acknowledged throughout Turkey as herd protection dogs (Ozbeyaz, 1994; Akcay, 2005; Yilmaz, 2008). This dog breed is alternatively known as "Karabash" as these dogs have a black mask around the nose and eyes, black ear tips and black eye color. In other countries, however, the Kangal shepherd dog is mostly known as either the "Anatolian Shepherd Dog" or "Anatolian Karabash". Ballard, who first exported these shepherd dogs to both England and the USA, referred this breed as "Anatolian Shepherd 
Dog" and this name has been generally accepted in many other countries (Atasoy and Kanli, 2005).

In many countries, Kangal shepherd dogs are preferred as herd protection and guard dogs. Kangal shepherd dogs are also employed in some countries for the preservation of endangered animal species. The Kangal shepherd dog can easily adapt to all conditions except humid hot weather (Reed, 2003; Kockaya and Sireli, 2015).

The considerable popularity of Kangal shepherd dogs is attributed to their tendency to perfectly execute orders and this in turn can be attributed to their excellent sensory organs. Hearing is critical for animals, as this sense is important in the environmental interactions (Stepien et al., 1990; Case, 2005). The auditory function may be decreased or completely lost for various reasons, or may be absent due to congenital reasons. Deafness can occur due to problems in the auditory conduction pathways and centers, or due to neurotransmission defects in general, as well as to congenital, genetic, ototoxic causes and to the otitis (Steel and Bock, 1983; Krahwinkel et al., 1993; SternBertholtz et al., 2003; Strain, 2004; Clark et al., 2006; Rizzi and Hirose, 2007; Hayes et al., 2010; Lv et al., 2010; Strain, 2011; Comito et al., 2012). Deafness is a pathological disorder that negatively affects the welfare of animals and stresses them (Keele et al., 1985). Although deaf animals can live, both deafness and impaired hearing negatively impact their performance. These problems can lead to estrangement of the dog with its owner, reduced interactions with other dogs and to injuries and deaths from attacks by wild animals or from vehicle accidents since the dog would not be alerted to noises.

Physical wellbeing of Kangal shepherd dogs is important, as this breed is mostly used in forage husbandry. Normal hearing function is an important health parameter for Kangal shepherd dogs because it gives them confidence and enables them to perform orders and perceive dangers. Impaired hearing of dogs would make herds more vulnerable to external threats, such as wild animal attacks and thefts, which results in economic losses.

The aim of this study was to estimate deafness risk for Kangal shepherd dogs in the Sivas province.

\section{Materials and Methods}

\section{Animals}

A total of 160 Kangal shepherd dogs were used. The dogs were obtained from local breeders and breeding establishments in the Sivas province. They were 87 females and 73 males and their ages ranged from 11 days to 10 years. The dogs were allowed to live in their routines to prevent both stress and artifact occurrences.

\section{BAER Method}

Brainstem Auditory Evoked Response (BAER) method was applied to all dogs by using a clinical Auditory Brainstem Response (ABR) device (Otometrics ICS Chartr EP 200, United States). Hearing values were recorded after dogs were made used to both the tester and the method for preventing possible stress conditions and artifacts.

Loudspeakers were positioned in right and left ears of all dogs and click stimuli were emitted in 20, 40, 60 and 80 decibel Hearing Level (dB HL), respectively. Hearing method was used for hearing calibration. Wave formations were monitored in PC screen. Deafness and hearing threshold ranges were determined by evaluations of wave formations.

\section{Statistical Analysis}

Ages, genders and general values of dogs were used to divide them into groups. Independent samples $t$-test was conducted for analysis of hearing threshold frequency differences between right and left ears of both general and gender groups. Dogs were divided into 3 age groups (20 days to 9 months, 10 to 30 months and 31 months or more). Comparisons were done by One-Way ANOVA with post-hoc Duncan test. All statistical calculations were performed by using SPSS v. 15 for Windows package software (SPSS Inc, 2006) and results were presented as mean \pm standard error of mean.

Informed consent: Permissions were granted from owners for client-owned animals used in the study.

Ethics committee approval was granted by the Cumhuriyet University Local Ethics Committee for Animal Experimentation (Issue: 65202830-050.04.0425; Date: 23.02.2016).

\section{Results}

\section{Hearing Sense Detection}

Fifth wave in hearing was obtained in 20, 40, 60 and $80 \mathrm{~dB}$ HL frequencies (Fig. 1).

No hearing function was detected in 7 pups that were of 11 days of age, which was indicating that the hearing function is not developed in this age for Kangal shepherd dog breed (Fig. 2).

One side deafness was determined only in two dogs. Hearing function was not detected in right ear of one dog (Fig. 3) and in left ear of the other dog (Fig. 4).

\section{Comparison Results of Groups}

Since hearing function was not detected in 7 pups of 11 days of age and in $2 \operatorname{dogs}, 9$ dogs were excluded from statistical analysis. Differences in hearing threshold frequency in 20,40,60 and $80 \mathrm{~dB}$ HL for 
right and lefts ears of remaining 151 dogs were analyzed for general values (Table 1), age (Table 2 and 3 ) and gender (Table 4 and 5) groups.

According to the Table 1, no significant difference in hearing thresholds between right and left ears was determined $(\mathrm{P}>0.05)$.
According to the Table 2, significant difference was determined in hearing thresholds of right ears in $80 \mathrm{~dB}$ HL frequency $(\mathrm{P}<0.05)$ and no significant difference was determined in hearing thresholds in other frequencies. No significant difference was determined in left ears in all frequencies $(\mathrm{P}>0.05)$ in gender groups (Table 3$)$.

Table 1: General comparisons of right and left ear (ms)

\begin{tabular}{|c|c|c|c|}
\hline \multicolumn{4}{|c|}{ RIGHT EAR $(\mathbf{n}=\mathbf{1 5 1})$} \\
\hline $20 \mathrm{~dB}$ & $\begin{array}{l}40 \mathrm{~dB} \\
(x+\mathrm{S} \times)\end{array}$ & $60 \mathrm{~dB}$ & $\begin{array}{l}80 \mathrm{~dB} \\
(\times \pm \mathrm{S} \times)\end{array}$ \\
\hline $4.90 \pm 0.05$ & $\begin{array}{r}4.39 \pm 0.04 \\
\text { LEFT }\end{array}$ & $3.93 \pm 0.04$ & $3.58 \pm 0.03$ \\
\hline $\begin{array}{l}20 \mathrm{~dB} \\
(\times \pm \mathrm{S} \times)\end{array}$ & $\begin{array}{l}40 \mathrm{~dB} \\
(\times \pm \mathrm{S} \times)\end{array}$ & $\begin{array}{l}60 \mathrm{~dB} \\
(\times \pm \mathrm{S} \times)\end{array}$ & $\begin{array}{l}80 \mathrm{~dB} \\
(\times \pm \mathrm{S} \times)\end{array}$ \\
\hline $4.80 \pm 0.05$ & $4.40 \pm 0.05$ & $4.01 \pm 0.04$ & $3.65 \pm 0.04$ \\
\hline $\mathrm{P}>0.05$ & $\mathrm{P}>0.05$ & $\mathrm{P}>0.05$ & $\mathrm{P}>0.05$ \\
\hline
\end{tabular}

ms: millisecond, $\mathrm{n}$ : sample number, $\times \pm \mathrm{S} \times$ : mean \pm standard error of mean

Table 2: Comparisons of right ear values according to genders (ms)

\begin{tabular}{|c|c|c|c|}
\hline \multicolumn{4}{|c|}{ FEMALE $(\mathbf{n}=\mathbf{8 5})$} \\
\hline $20 \mathrm{~dB}$ & $40 \mathrm{~dB}$ & $60 \mathrm{~dB}$ & $\begin{array}{l}80 \mathrm{~dB} \\
(x+\mathrm{S} x)\end{array}$ \\
\hline $\begin{array}{l}(\times \pm \mathrm{S} \times) \\
4.89 \pm 0.07\end{array}$ & $\begin{array}{l}(\times \pm \mathrm{S} \times) \\
4.35 \pm 0.06\end{array}$ & $\begin{array}{l}(\times \pm \mathrm{S} \times) \\
3.89 \pm 0.05\end{array}$ & $3.51 \pm 0.05^{\mathrm{a}}$ \\
\hline \multicolumn{4}{|c|}{ MALE $(\mathbf{n}=\mathbf{6 6})$} \\
\hline $20 \mathrm{~dB}$ & $40 \mathrm{~dB}$ & $60 \mathrm{~dB}$ & $80 \mathrm{~dB}$ \\
\hline $\begin{array}{l}(\times \pm \mathrm{S} \times) \\
4.92 \pm 0 \quad 08\end{array}$ & $\begin{array}{l}(\times \pm \mathrm{S} \times) \\
443+0.06\end{array}$ & $\begin{array}{l}(\times \pm \mathrm{S} \times) \\
399+0.06\end{array}$ & $\begin{array}{l}(\times \pm S \times) \\
366 \pm 005^{b}\end{array}$ \\
\hline \multicolumn{4}{|c|}{$P$ value } \\
\hline $\mathrm{P}>0.05$ & $\mathrm{P}>0.05$ & $\mathrm{P}>0.05$ & $\mathrm{P}<0.05$ \\
\hline
\end{tabular}

ms: millisecond, $\mathrm{n}$ : sample number, $\times \pm \mathrm{S} \times$ : mean \pm standard error of mean

Table 3: Comparisons of left ear values according to genders (ms)

\begin{tabular}{|c|c|c|c|}
\hline \multicolumn{4}{|c|}{ FEMALE $(\mathbf{n}=\mathbf{8 5})$} \\
\hline $\begin{array}{l}20 \mathrm{~dB} \\
(\times \pm \mathrm{S} \times)\end{array}$ & $\begin{array}{l}40 \mathrm{~dB} \\
(\times \pm \mathrm{S} \times)\end{array}$ & $\begin{array}{l}60 \mathrm{~dB} \\
(\times \pm \mathrm{S} \times)\end{array}$ & $\begin{array}{l}80 \mathrm{~dB} \\
(\times \pm \mathrm{S} \times)\end{array}$ \\
\hline $4.75 \pm 0.07$ & $4.36 \pm 0.07$ & $3.96 \pm 0.06$ & $3.63 \pm 0.06$ \\
\hline $\begin{array}{l}20 \mathrm{~dB} \\
(\times \pm \mathrm{S} \times)\end{array}$ & $\begin{array}{l}40 \mathrm{~dB} \\
(\times \pm \mathrm{S} \times) \\
446 \pm 0.07\end{array}$ & $\begin{array}{l}60 \mathrm{~dB} \\
(\times \pm \mathrm{S} \times) \\
407 \pm 0.07\end{array}$ & $\begin{array}{l}80 \mathrm{~dB} \\
(\times \pm \mathrm{S} \times) \\
3.68 \pm 0.07\end{array}$ \\
\hline \multicolumn{4}{|c|}{$P$ value } \\
\hline $\mathrm{P}>0.05$ & $\mathrm{P}>0.05$ & $\mathrm{P}>0.05$ & $\mathrm{P}>0.05$ \\
\hline
\end{tabular}

ms: millisecond, $\mathrm{n}$ : sample number, $\times \pm \mathrm{S} \times$ : mean \pm standard error of mean

Table 4: Comparisons of right ear values according to ages (ms)

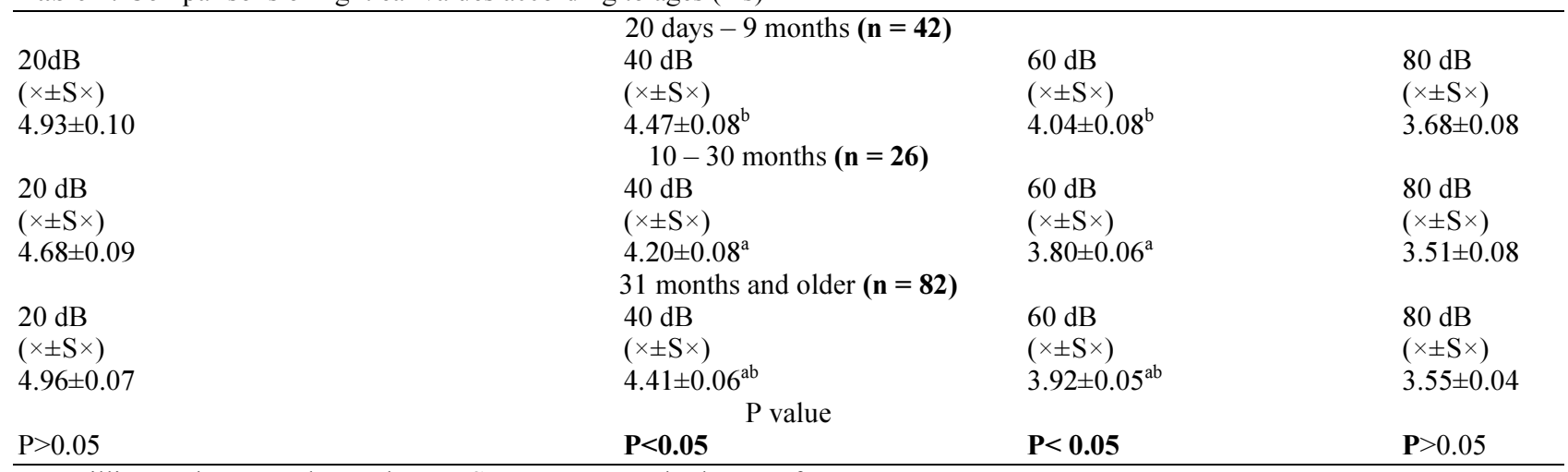

ms: millisecond, $\mathrm{n}$ : sample number, $\times \pm \mathrm{S} \times$ : mean \pm standard error of mean 
Mustafa Koçkaya et al. / American Journal of Animal and Veterinary Sciences 2019, 14 (2): 115.121 DOI: 10.3844/ajavsp.2019.115.121

Table 5: Comparisons of left ear values according to ages (ms)

\begin{tabular}{|c|c|c|c|}
\hline \multicolumn{4}{|c|}{20 days -9 months $(n=42)$} \\
\hline $20 \mathrm{~dB}$ & $40 \mathrm{~dB}$ & $60 \mathrm{~dB}$ & $80 \mathrm{~dB}$ \\
\hline$(\times \pm \mathrm{S} \times)$ & $(\times \pm \mathrm{S} \times)$ & $(\times \pm \mathrm{S} \times)$ & $(\times \pm \mathrm{S} \times)$ \\
\hline $4.91 \pm 0.11$ & $4.50 \pm 0.11$ & $4.10 \pm 0.09$ & $3.76 \pm 0.09$ \\
\hline \multicolumn{4}{|c|}{$10-30$ months $(\mathbf{n}=\mathbf{2 6})$} \\
\hline $20 \mathrm{~dB}$ & $40 \mathrm{~dB}$ & $60 \mathrm{~dB}$ & $80 \mathrm{~dB}$ \\
\hline$(\times \pm \mathrm{S} \times)$ & $(\times \pm \mathrm{S} \times)$ & $(\times \pm \mathrm{S} \times)$ & $(\times \pm \mathrm{S} \times)$ \\
\hline $4.63 \pm 0.09$ & $4.26 \pm 0.10$ & $3.86 \pm 0.09$ & $3.57 \pm 0.08$ \\
\hline \multicolumn{4}{|c|}{31 months and older $(\mathbf{n}=\mathbf{8 2})$} \\
\hline $20 \mathrm{~dB}$ & $40 \mathrm{~dB}$ & $60 \mathrm{~dB}$ & $80 \mathrm{~dB}$ \\
\hline$(\times \pm \mathrm{S} \times)$ & $(\times \pm \mathrm{S} \times)$ & $(\times \pm \mathrm{S} \times)$ & $(\times \pm \mathrm{S} \times)$ \\
\hline $4.79 \pm 0.07$ & $4.40 \pm 0.06$ & $4.01 \pm 0.06$ & $3.62 \pm 0.06$ \\
\hline \multicolumn{4}{|c|}{ P value } \\
\hline $\mathrm{P}>0.05$ & $\mathrm{P}>0.05$ & $\mathrm{P}>0.05$ & $\mathrm{P}>0.05$ \\
\hline
\end{tabular}

ms: millisecond, $\mathrm{n}$ : sample number, $\times \pm \mathrm{S} \times$ : mean \pm standard error of mean

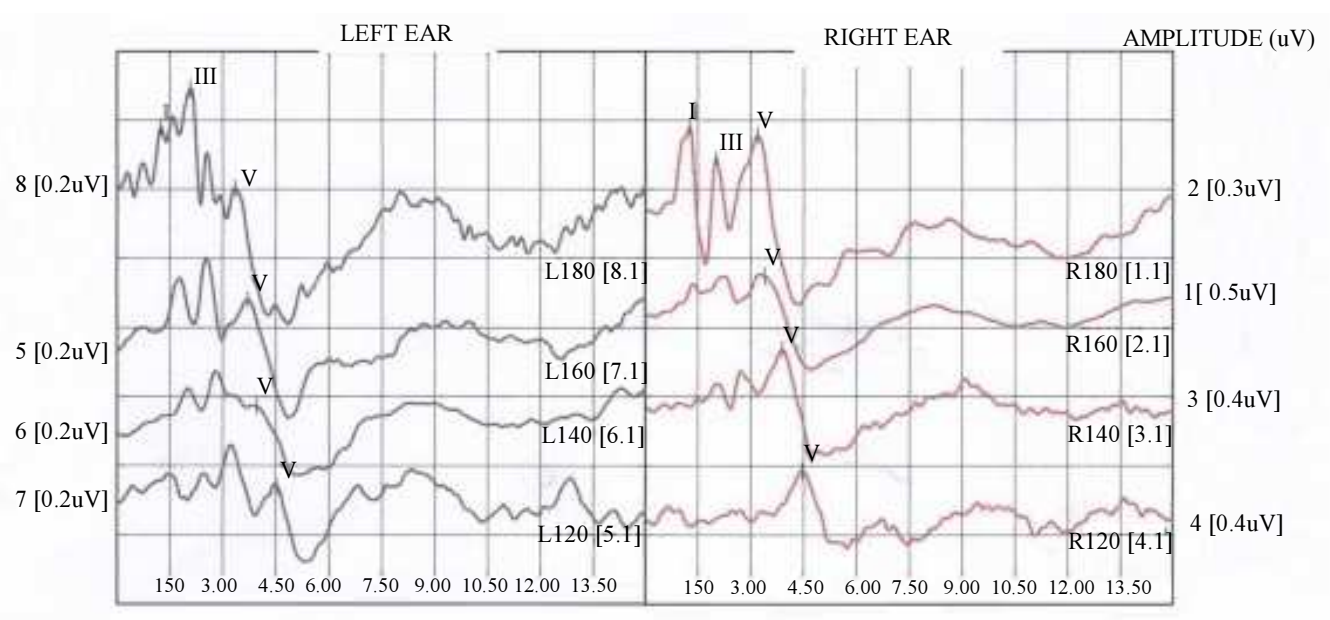

Time (ms)

Fig. 1: Obtained hearing waves

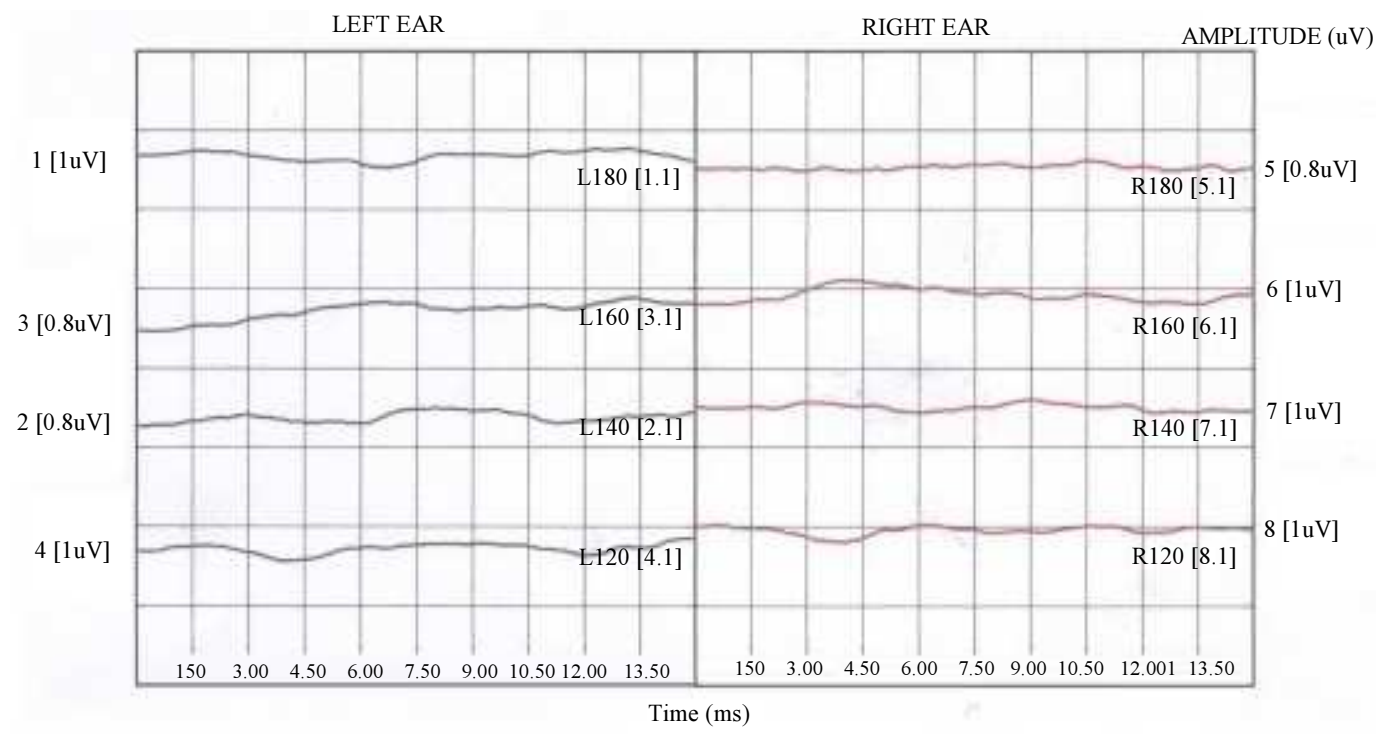

Fig. 2: Hearing wave result obtained from 11 days old pup 


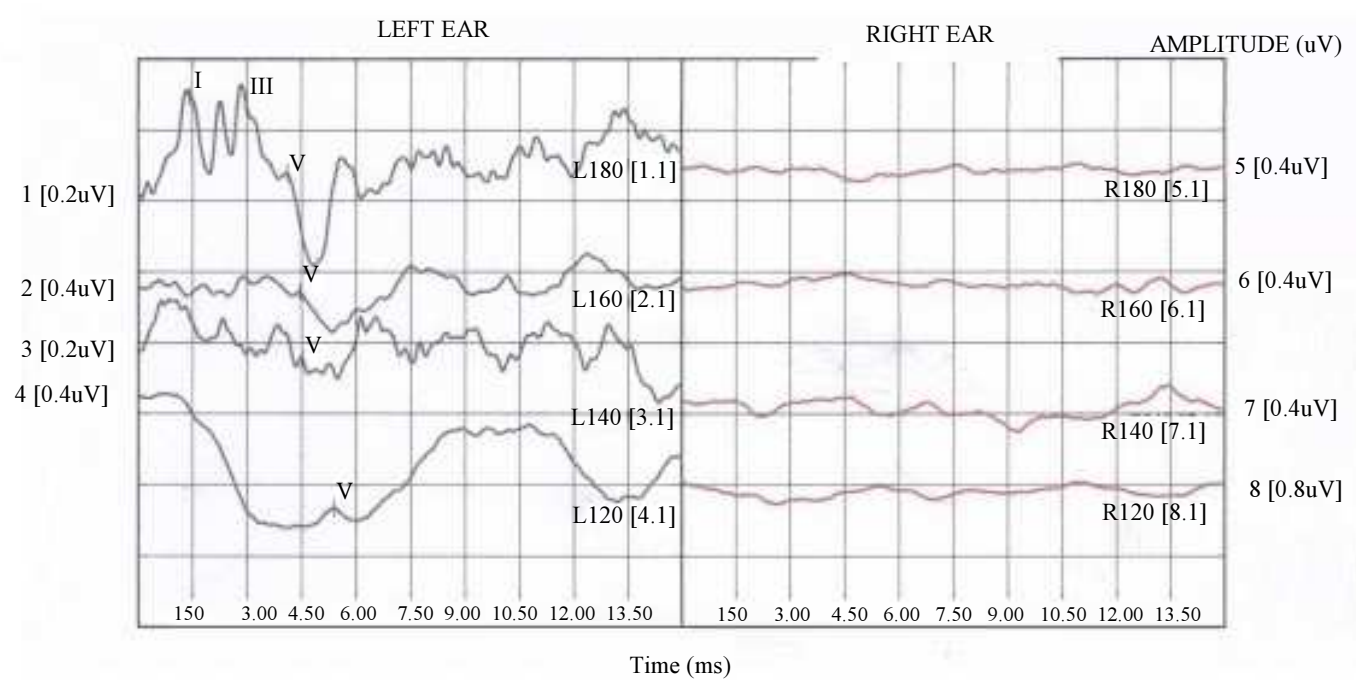

Fig. 3: Wave result of the dog having right ear deafness

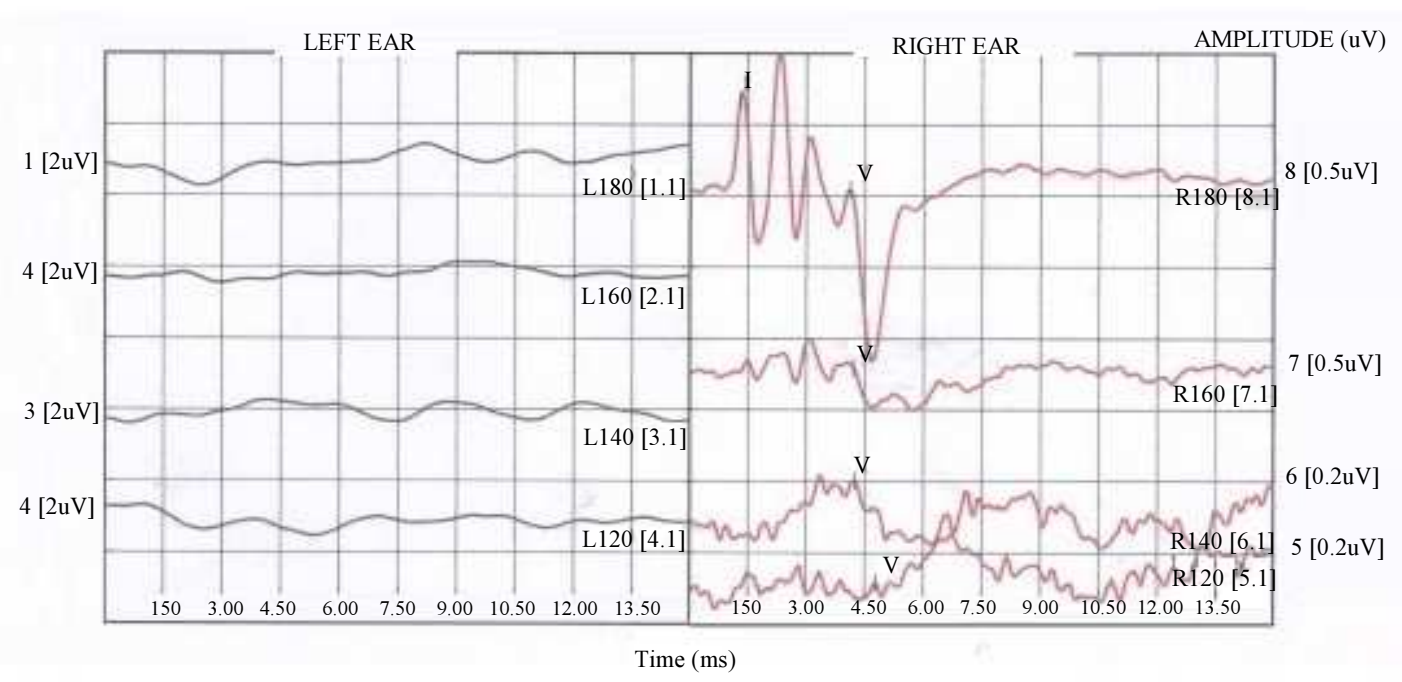

Fig. 4: Wave result of the dog having left ear deafness

According to the Table 4, significant difference was determined in hearing thresholds of right ears in 40 and $60 \mathrm{~dB}$ HL frequencies in age groups $(\mathrm{P}<0.05)$. In 40 and $60 \mathrm{~dB}$ HL frequencies, 31 months old and older dogs were determined as similar to other dogs (20 days to 9 months old and 10 to 30 months old dogs). Dogs that were 10 to 30 months old were determined to have lower frequencies compared to others. No significant difference was determined in right ears in other frequencies $(\mathrm{P}>0.05)$.

According to the Table 5, no significant difference was determined in hearing thresholds in left ears in all frequencies $(\mathrm{P}>0.05)$ in age groups.

\section{Discussion}

No other deafness estimation and hearing detection studies in native dog breeds of Turkey were present in the literature. Therefore, this study is the first where deafness estimation was conducted in Kangal shepherd dog breed, one of the native genetic resources of Turkey.

Previous research (Strain, 2004; 2011; 2012) and a website (Strain, 2018) were reported deafness in $104 \mathrm{dog}$ breeds. Kangal shepherd dog breed, which is mentioned as Anatolian shepherd dog, was reported in the website to have deafness. However, it was stated that the report was based on verbal expressions of breeders (based on interview with Strain). Despite this report, there were no 
scientific data or conducted research for the deafness in Kangal shepherd dog breed. The present study is the first to provide scientific data in this issue by conducting deafness estimation in 160 Kangal shepherd dogs in Sivas province. Deafness were scientifically estimated for the first time in 2 Kangal shepherd dogs that were of 5 years and 6 months old, respectively. Right ear deafness was detected in one dog (Fig. 3) and left ear deafness was detected in the other dog (Fig. 4).

Hearing function in dogs was reported to become functional 13 to 17 days after birth (Ciftci, 1993). Exact determination of this trait was not presented yet in the literature. Hearing sense detection was conducted in 7 pups that were of 11 days of age for this purpose. It was determined that no hearing function was present in that age (Fig. 2). Therefore, a significant contribution to the field was achieved. Pups that were of 20 days old were determined to have hearing function in the study.

Dogs were divided into 3 groups in the study and groups were investigated for differences in hearing thresholds in left and right ears in 20, 40, 60 and $80 \mathrm{~dB}$ HL frequencies. Basically, no difference was determined for left and right ears (Table 1). Therefore, it was determined that dogs have similar hearing thresholds in left and right ears.

Investigations in gender groups (Table 2 and 3) were revealed differences in right ears in 40 and $60 \mathrm{~dB}$ HL frequencies and were revealed no difference for other frequencies in right ears and were revealed no difference in all frequencies in left ears. It was determined that female dogs have better hearing thresholds in right ears in 40 and $60 \mathrm{~dB}$ HL frequencies compared to males. According to these results, keeping female and male dogs together in their advanced ages for herd protection is recommended.

Age groups (Table 4 and 5) were created according to breeder statements and to the cranial development periods which is used for determination of the growth. Pups that were 11 days old were excluded from groups since they provided no hearing function. Therefore, groups were started with pups that were 20 days old. In the end, 3 age groups were created and groups were divided to include dogs that were of 20 days to 9 months of age, dogs that were 10 to 30 months of age and dogs that were 31 months of age or more. Significant difference was determined in hearing thresholds in right ears in 40 and $60 \mathrm{~dB}$ HL frequency $(\mathrm{P}<0.05)$. In both 40 and $60 \mathrm{~dB}$ frequencies, dogs that were of 31 months of age or more were determined to be similar to dogs that were of 10 to 30 months and 20 days to 9 months of age. However, it was determined that dogs that were of 10 to 30 months of age have lower frequencies compared to others. Other frequencies for right ear were provided no significant difference $(\mathrm{P}>0.05)$. It is recommended to include Kangal pups in herds after 10 months of age and to keep pups with adults in order for them to improve their adaptation and behavior. Being together with adults would also provide protection to pups against external threats like wolves.

\section{Conclusion}

In this study, deafness was estimated in two Kangal shepherd dogs from a total of 160 dogs in Sivas province and which is a specific genetic resource in Turkey. From an economic point of view, Kangal shepherd dogs with deafness should be kept in the farm since they would be lagging behind other dogs and would not perform their duties well enough in herd protection. The benefit to utilization rate of the deaf dogs and their offspring would be low. Likewise, the benefit to cost rate of deaf dogs would remain lower than the other healthy members in terms of return on the investment made by the company. In terms of Kangal shepherd dog breeding establishments, this would also reduce profitability while increasing expenses. Therefore, having deaf dogs in breeding would severely reduce the profit and undermine the business. In terms of effective herd management, deaf dogs should not be used in breeding since deafness can also be transmitted genetically to offspring.

\section{Acknowledgement}

The authors acknowledge the contributions of breeders, Cumhuriyet University Kangal Dog Breeding and Research Facility administration, Kangal district governorship to sampling efforts and acknowledge the assistances provided from veterinary physicians Mehmet Ali ERYILMAZ, Tolga ERDOGANOGLU and Gökhan KACAN and to Sivas Cumhuriyet University Faculty of Veterinary Medicine trainee Hasan AKTAS.

\section{Funding Information}

This research was supported by the Scientific Research Project Fund of Sivas Cumhuriyet University under the project number V-043. The study was presented as an oral presentation at International Eurasian Conference on Biological and Chemical Sciences (EurasianBioChem 2018), 26-27 April 2018, Ankara, Turkey.

\section{Author's Contributions}

Mustafa Koçkaya: He carried out field work. He conceived of the study and participated in its design and coordination and helped to draft the manuscript.

Yusuf Özşensoy: He carried out field work. He participated in the design of the study and performed the statistical analysis and helped to draft the manuscript.

Hakan Murat: He carried out field work. He helped to draft the manuscript and made an economic comment. 


\section{Competing Interests}

The authors declare that there is no conflict of interests regarding the publication of this article. All authors read and approved the final manuscript.

\section{References}

Akcay, E., 2005. Anadolu'nun özgün hayvanları: Kangal çoban köpeği. Veteriner Hekimler Derneği Dergisi, 76: $72-74$.

Atasoy, F and O. Kanli., 2005. Türk çoban köpeği Kangal. 2. Baskı, Medisan Yayıncılık, Ankara, Türkiye.

Case, L.P., 2005. The Dog: Its Behavior, Nutrition and Health. 2nd Edn., Blackwell Publishing, UK. ISBN-10: 0813812542.

Cevik, M., 2011. Evliya Çelebi Seyahatnamesi. 10 cilt, Üçdal Neşriyat, İstanbul, Türkiye, ISBN: 9786055317003.

Ciftci, A., 1993. Dostum Köpek. TÜBİTAK Bilim ve Teknik Dergisi, Aralık, 1993: 928-935.

Clark, L.A., J.M. Wahl, C.A. Rees and K.E. Murphy, 2006. Retrotransposon insertion in SILV is responsible for merle patterning of the domestic dog. PNAS, 103: 1376-1381.

DOI: $10.1073 /$ pnas.0506940103.

Comito, B., K.E. Knowles and G.M. Strain, 2012. Congenital deafness in Jack Russell terriers: prevalence and association with phenotype. Vet. J., 193: 404-407. DOI: 10.1016/j.tvj1.2012.02.018.

Coppinger, R. L., L. Coppinger and M. Harned, 1996. The importance of dogs in guarding the flock in the USA. Proceedings of the International Symposium on Turkish Shepherd Dogs, Oct. 23, Konya, Turkey, pp: 171-195.

Dawydiak, O. and D.E. Sims, 2004. Livestock Protection Dogs: Selection, Care and Training. 2nd Edn., Alpine Blue Ribbon Books, Loveland, Colorado. ISBN: 1-57779-062-6.

Hayes, G.M., E.J. Friend and N.D. Jeffery, 2010. Relationship between pharyngeal conformation and otitis media with effusion in Cavalier King Charles spaniels. Vet. Record, 167: 55-58.

DOI: $10.1136 /$ vr.b4886.

Jensen, P., 2007. The behavioural biology of dogs. CABI Publisher, Oxfordshire, UK.

Keele, C.A., E. Neil and N. Joels, 1985. Samson Wright's Applied Physiology. 13th Edn., Oxford Univ Press, London, New York, Toronto, USA. ISBN10: 0192632108.

Kockaya, M. and M. Sireli, 2015. Comparison of behavioural and physiological responses of Kangal dogs in different livestock flocks. Ankara Üniversitesi Veteriner Fakültesi Dergisi, 62: 261-267. DOI: 10.1501/Vetfak_0000002690.
Krahwinkel, D.J., A.D. Pardo, M.H. Sims and W.J. Bubb, 1993. Effect of total ablation of the external acoustic meatus and bulla osteotomy on auditory function in dogs. J. Am. Vet. Med. Association, 202: 949-952.

Lv, P., D. Wei and E.N. Yamoah 2010. Kv7-type channel currents in spiral ganglion neurons: involvement in sensorineural hearing loss. J. Bio. Chem., 285: 34699-34707. DOI: $10.1074 / j b c . M 110.136192$

Nelson, D.D., 1996. A general classification of the native dogs of Turkey. Proceedings of the International Symposium Turkish Shepherd Dogs. Oct. 23, Konya, Turkey, pp: 19-96.

Ozbeyaz, C., 1994. Kangal köpeklerinde bazı morfolojik özellikler. Lalahan Hayvancılık Araştırma Enstitüsü Dergisi, 34: 38-46.

Reed, S., 2003. İngiltere ve Avrupa'da Türk köpekleri. Proceedings of the 1st International Symposium Turkish Shepherd Dogs, July 11, Sivas, Turkey.

Rizzi, M.D. and K. Hirose, 2007. Aminoglycoside ototoxicity. Curr. Opin. Otolaryngol. Head Neck Surgery, 15: 352-357. DOI: $10.1097 / \mathrm{MOO} .0 \mathrm{~b} 013 \mathrm{e} 3282 \mathrm{ef} 772 \mathrm{~d}$

SPSS Inc, 2006. SPSS 15.0 for Windows Evalution Version.

Steel, K.P. and G.R. Bock, 1983. Hereditary inner-ear abnormalities in animals. Archives OtolaryngologyHead Neck Surgery, 109: 22-29. DOI: 10.1001/archotol.1983.00800150026005

Stepien, I., L. Stepien and E. Lubinska, 1990. Function of dog's auditory cortex in tests involving auditory location cues and directional instrumental response. Acta Neurobiologiae Experimentalis, 50: 1-12.

Stern-Bertholtz, W., L. Sjostrom and N.W. Harkanson, 2003. Primary secretory otitis media in the Cavalier King Charles spaniel: A review of 61 cases. J. Small Animal Practice, 44: 253-256.

DOI: 10.1111/j.1748-5827.2003.tb00151.x.

Strain, G.M., 2004. Deafness prevalence and pigmentation and gender associations in dog breeds at risk. Vet. J., 167: 23-32. DOI: 10.1016/S1090-0233(03)00104-7

Strain, G.M., 2011. Physiology of the Auditory System. In: Deafness Dogs Cats, Strain, G.M. (Ed), CABI, Wallingford, UK, pp: 23-39. ISBN-13: 9781845939373.

Strain, G.M., 2012. Canine deafness. Vet. Clinics North America-Small Animal Practice, 42: 1209-1224. DOI:10.1016/j.cvsm.2012.08.010.

Strain, G.M., 2018. Dog breeds with reported congenital deafness. Deafness Dogs Cats.

Yilmaz, O., 2008. Kangal (Karabaş) Türk çoban köpeği. Bilge Kültür Sanat, İstanbul, Türkiye. ISBN-13: 9789944425933. 